\title{
Impact of Socio-Demographic Characteristics on Attitude of Ever Married Women Towards Gender Based Violence in Egypt: Secondary Analysis of SYPE Data, 2014
}

\author{
SABRA M. AHMED, M.D. and FATEN M. RABIE, M.D. \\ The Department of Public Health and Community Medicine, Faculty of Medicine, Assiut University, Egypt
}

\begin{abstract}
Background: To identify the impact of socio demographic factors on attitude of ever married female toward violence against women in Egypt.

Material and Methods: Data from Survey of Young People in Egypt (SYPE), 2014 were used in this study. Attitude towards Gender-Based Violence (GBV) and sociodemographic characteristics of 3,226 ever married females aged 13-35 years were selected for secondary and advanced analysis.

Results: Only a small percentage $(28.7 \%)$ of all ever married female youth rejected gender-based violence. The rejection of GBV was increased with increasing the wealth quintile from the lowest to the richest level $(p<0.001)$. There were no statistical significant differences between respondents who accepted the GBV attitude and those who reject it as regard the employment status $(p=0.442)$. There was more rejection of GBV with increasing educational level of respondents and their parents from illiterate to university or higher level $(p<0.001)$. Agreement to GBV increased by increasing the number of brothers and sisters $(p=0.021)$.

Conclusion: Sociodemographic characteristics play an important role on the attitude of ever married women towards violence against women.

Recommendations: Parents, educational institutions, health care providers (e.g. pre-marital counseling), civil society (mass media), community and religious leaders need to engage in more open dialog with young people to educate them about GBV, enforce positive attitude (multi-sectoral interventions) and support economic and social development.
\end{abstract}

Key Words: Sociodemographic - Ever married - Women Violence.

\section{Introduction}

THE United Nations defines violence against women as "any act of gender-based violence that

Correspondence to: Dr. Sabra M. Ahmed, The Department of Public Health and Community Medicine, Faculty of Medicine, Assiut University, Egypt results in, or is likely to result in, physical, sexual, or mental harm or suffering to women, including threats of such acts, compulsion, or arbitrary deprivation of freedom, whether occurring in public or in private life." [1]

Violence against women occurs everywhere and all the times irrespective of ethnicity, class, religion, age, sexuality, culture and geographic region. Victims of violence may suffer from sexual and reproductive health consequences, which could include forced and unwanted pregnancies, unsafe abortions, traumatic fistula, sexually transmitted diseases including HIV, and even death [2]. Violence has both physical and emotional harms on the victims and it has both a health and a human rights concern [2]. Violence prevents both women and societies from achieving their full potential [2].

EDHS, 2014 reported that, about 30\% evermarried women aged 15-49 years in Egypt have ever experienced some form of spousal violence, with $25 \%$ saying they were subjected to physical violence, $19 \%$ emotional violence, and $4 \%$ sexual violence. Almost one-fifth of women were the target of an episode of spousal violence within the last 12 months, more than 1 in 3 women experiencing spousal physical or sexual violence are injured as a result of the violence, and $7 \%$ have serious injuries. Husbands were the most common perpetrators of violence [3]. Attitudes have been a key target of community education campaigns aimed at preventing violence against women. There is lack of studies about the factors that affects the attitudes towards violence against women [4]

This study aimed to identify the attitude of ever married female youth in Egypt toward gender based violence and its sociodemographic correlates. 


\section{Patients and Methods}

Data from Survey of Young People in Egypt (SYPE), 2014 were used in this study. The SYPE adopted a multistage stratified cluster sampling all over Egypt to select 10,916 eligible young people aged 13-35 years. An interview questionnaire was used to collect detailed data related to education, employment, migration, health, risky behaviors, violence, family formation, social issues, and civic and political participation. The violence attitude was selected and its explanatory variables of 3,226 ever married females aged 13-35 years for secondary and advanced analysis.

\section{Data processing:}

A- Obtaining data files.

B- Selection of ever married females.

C- Recoding of some variables.

Attitude towards gender based violence (Q4145):

SYPE, 2014 questionnaires asked respondents six questions (Q4145) to indicate the contexts in which it isjustifiable for a husband to beat his wife:

1 - If she burnt the food.

2- If she neglected children.

3- If she argued with the husband.

4- If she talked to another man.

5- If she wasted her husband's money.

6- If she refused to have sex with the husband.

Those who answered no for all these questions were considered rejecting gender-based violence and those who answered yes for one or more of these questions were considered accepting genderbased violence. This was done by recoding of answers to be (0) for those who disagree (reject) violence and (1) for those who agree (accept) any form of violence. Then summation of the codes of this group of questions. Those with score of zero were considered rejecting gender based violence and those with score of one to sixwere considered as accepting gender based violence.

\section{Data analysis:}

Data analysis was done by using Statistical Package for Social Science (SPSS, Version 20). Data was analyzed using univariate analysis (frequency tables), bivariate analysis (cross tabulations) using chi-square test and $t$-test with a level of significance $<0.05$ and multivariate analyses (binary logistic regressions) for statistically significant variables were carried out.
Gender-based violence attitude was the dependent variable. Socio-demographic characteristics like age at marriage of respondents, residence, education of respondents and their parents, employment status of respondents, number of brothers and sisters, consanguinityamong parents, family type and wealth quintile constituted the independent variables.

\section{Results}

Table (1) showed that, a total 3,226 of ever married females were included in the study. The majority of the study population was 18 years or more. The mean age was $20.1 \pm 4.3$. About two thirds of the study population was rural residents (66.4\%) and $42.3 \%$ of the participants had secondary education. Most $(89.7 \%)$ of the studied women were un-employed. Nearly one fifth of each study population was distributed in each class of the wealth quintile. The majority of participants $(71.9 \%)$ had non-consanguineous marriage. On the other hand, two thirds $(66.6 \%)$ of studied women lived in nuclear families.

Only $28.7 \%$ of respondents rejected gender based violence compared with $71.3 \%$ accepted gender based violence.

Table (2) shows that the respondents with older age at marriage (18 years or more) were more likely to reject (29.6\%) GBV than those with younger age at marriage $(25.3 \%)$. The difference was statistically significant $(p=0.028)$.

Respondents from Upper Egypt whether rural or urban areas were less likely to reject GBV than those from Lower Egypt or urban governorates with high significant difference $(p<0.001)$.

As regard the respondents' education, there was more rejection of GBV attitude with increasing the level of education from illiterate $(24.0 \%)$ to university or higher level $(38.2 \%)$ with high significant difference $(p<0.001)$.

Similarly, father's education, with increasing the level of education, the rejection of GBV increased. $26.1 \%$ of respondents with illiterate fathers rejected GBV compared to $34.1 \%$ of those who had secondary or higher education, with high significant difference $(p<0.001)$.

Respondents with nuclear family were more likely to reject GBV (31.1\%) than those with extended family $(24 \%)$, with high significant difference $(p<0.001)$. 
Agreement to GBV increased by increasing the number of brothers and sisters. The difference was significant $(p=0.021)$.

There was no significant statistical difference between respondents who accepted the GBV attitude and those who rejected it as regard the employment status $(p=0.442)$. Also, there was no significant difference regarding consanguineous marriage.

Regarding wealth quintile, the rejection of GBV was increased with increasing the wealth quintile from the lowest level $(22.5 \%)$ to the highest level $(31.0 \%)$ with high significant difference $(p<0.001)$.

Table (3) shows that by using logistic regression analysis, residing in Urban governorate, lower Egypt (whether urban or rural), and Frontier governorates, secondary and higher education, are significantly associated with higher probability of rejecting GBV.

Table (1): Socio-demographic characteristics of ever married female youth in Egypt, SYPE, 2014.

\begin{tabular}{|c|c|}
\hline Characteristics & Frequency $(\%)$ \\
\hline $\begin{array}{l}\text { Age at marriage: } \\
\quad<18 \text { years } \\
\quad \geq 18 \text { years } \\
\text { Mean }( \pm \mathrm{SD})\end{array}$ & $\begin{array}{l}675(20.9) \\
2551(79.1) \\
20.1 \pm 4.3\end{array}$ \\
\hline $\begin{array}{l}\text { Urban-rural residence: } \\
\text { Urban } \\
\text { Rural }\end{array}$ & $\begin{array}{l}1084(33.6) \\
2142(66.4)\end{array}$ \\
\hline $\begin{array}{l}\text { Place of residence: } \\
\text { Urban governorates } \\
\text { Urban Lower Egypt } \\
\text { Rural Lower Egypt } \\
\text { Urban Upper Egypt } \\
\text { Rural Upper Egypt } \\
\text { Frontier Governorates }\end{array}$ & $\begin{array}{l}470(14.6) \\
325(10.1) \\
1122(34.8) \\
158(4.9) \\
899(27.9) \\
252(7.8)\end{array}$ \\
\hline $\begin{array}{l}\text { Respondent's education: } \\
\text { Illiterate } \\
\text { Basic education } \\
\text { Secondary education } \\
\text { High education }\end{array}$ & $\begin{array}{l}726(22.5) \\
665(20.6) \\
1366(42.3) \\
469(14.5)\end{array}$ \\
\hline $\begin{array}{l}\text { Employment status: } \\
\text { Employed } \\
\text { Un-employed }\end{array}$ & $\begin{array}{l}332(10.3) \\
2894(89.7)\end{array}$ \\
\hline $\begin{array}{l}\text { Consanguinity: } \\
\text { Non-consanguineous } \\
\text { Consanguineous: } \\
\text { - First-cousin } \\
\text { - Other relative } \\
\text { - Total consanguineous }\end{array}$ & $\begin{array}{l}2319(71.9) \\
407(12.6) \\
500(15.5) \\
907(28.1)\end{array}$ \\
\hline $\begin{array}{l}\text { Family type: } \\
\text { Nuclear } \\
\text { Extended }\end{array}$ & $\begin{array}{c}2148(66.6) \\
1077(33.4)\end{array}$ \\
\hline $\begin{array}{c}\text { Gender-based violence att } \\
\text { Positive }=\text { Reject GBV } \\
\text { Negative }=\text { Accept GBV }\end{array}$ & $\begin{array}{l}927(28.7) \\
2299(71.3)\end{array}$ \\
\hline Total & $3226(100.0)$ \\
\hline
\end{tabular}

Table (2): Attitude towards gender-based violence among ever married female youth in Egypt by socio-demographic characteristics, 2014.

\begin{tabular}{|c|c|c|c|}
\hline \multirow[b]{2}{*}{ Characteristics } & \multicolumn{2}{|c|}{ GBV attitude } & \multirow{2}{*}{$\underset{\text { value }}{p^{-}}$} \\
\hline & $\begin{array}{c}\text { Reject GBV } \\
927(28.7)\end{array}$ & $\begin{array}{l}\text { Accept GBV } \\
2299(71.3)\end{array}$ & \\
\hline \multicolumn{4}{|l|}{ Age at marriage: } \\
\hline$<18$ years & $171(25.3)$ & $504 \quad(74.7)$ & 0.028 \\
\hline$\geq 18$ years & $756(29.6)$ & $1795(70.4)$ & \\
\hline Mean $( \pm \mathrm{SD})$ & $20.5 \pm 4.9$ & $20.0 \pm 4.0$ & $0.004 *$ \\
\hline \multicolumn{4}{|l|}{ Urban-rural residence: } \\
\hline Urban & $386(35.6)$ & $698 \quad(64.4)$ & $<0.001$ \\
\hline Rural & $541(25.3)$ & $1601(74.7)$ & \\
\hline \multicolumn{4}{|l|}{ Place of residence: } \\
\hline Urban Governorates & $162(34.5)$ & $308(65.5)$ & $<0.001$ \\
\hline Urban Lower Egypt & $157(48.3)$ & $168(51.7)$ & \\
\hline Rural Lower Egypt & $342(30.5)$ & $780(69.5)$ & \\
\hline Urban Upper Egypt & $21 \quad(13.3)$ & $137(86.7)$ & \\
\hline Rural Upper Egypt & $164(18.2)$ & $735(81.8)$ & \\
\hline Frontier Governorates & $81 \quad(32.1)$ & $171(67.9)$ & \\
\hline \multicolumn{4}{|l|}{ Wealth quintile: } \\
\hline Lowest & $140(22.5)$ & $481(77.5)$ & $<0.001$ \\
\hline Second & $173(25.2)$ & $514(74.8)$ & \\
\hline Middle & $196(31.5)$ & $426(68.5)$ & \\
\hline Fourth & $216(33.4)$ & $430(66.6)$ & \\
\hline Richest & $201(31.0)$ & $448(69.0)$ & \\
\hline \multicolumn{4}{|l|}{ Employment status: } \\
\hline Employed & $103(31.0)$ & $229 \quad(69.0)$ & 0.330 \\
\hline Un-employed & $824(28.5)$ & $2070(71.5)$ & \\
\hline \multicolumn{4}{|l|}{ Respondent's education: } \\
\hline Illiterate & $174(24.0)$ & $552(76.0)$ & $<0.001$ \\
\hline Basic education & $157(23.6)$ & $508(76.4)$ & \\
\hline Secondary education & $417(30.5)$ & $949(69.5)$ & \\
\hline High education & $179(38.2)$ & $290(61.8)$ & \\
\hline \multicolumn{4}{|l|}{ Father's education: } \\
\hline Illiterate & $486(26.1)$ & 1379 (73.9) & $<0.001$ \\
\hline Read and write & $150(33.9)$ & $292 \quad(66.1)$ & \\
\hline Basic education & $124(31.4)$ & $271 \quad(68.6)$ & \\
\hline 2ry and higher & $152(34.1)$ & $294 \quad(65.9)$ & \\
\hline \multicolumn{4}{|l|}{ Consanguineous marriage: } \\
\hline No & $659(28.4)$ & $1660(71.6)$ & 0.523 \\
\hline Yes & $268(29.5)$ & $639 \quad(70.5)$ & \\
\hline
\end{tabular}

Table (2): Continued.

\begin{tabular}{llll}
\hline & \multicolumn{2}{c}{ GBV attitude } & \\
\cline { 2 - 3 } Characteristics & $\begin{array}{c}\text { Reject GBV } \\
927(28.7)\end{array}$ & $\begin{array}{c}\text { Accept GBV } \\
2299(79.7)\end{array}$ & value \\
\hline $\begin{array}{l}\text { Family type: } \\
\quad \begin{array}{l}\text { Nuclear } \\
\quad \text { Extended }\end{array}\end{array}$ & $667(31.1)$ & $1481(68.9)$ & $<0.001$ \\
$\begin{array}{l}\text { - Mean No. of brothers } \\
\text { and sisters }( \pm \text { SD) }\end{array}$ & $5.0 \pm 2.7$ & $5.2 \pm 2.7$ & $0.021 *$ \\
\hline $\begin{array}{l}\text { Chi square test was used. } \\
*: t \text {-test was used. }\end{array}$ & & & \\
\end{tabular}


Table (3): Logistic regression analysis for variables related to gender-based violence among ever married female youth in Egypt, 2014.

\begin{tabular}{lll}
\hline Variables & Odds ratio (95\% CI) & $p$-value \\
\hline Current place of residence: & & \\
$\quad$ Urban Upper Egypt & 1 (baseline) & 0.000 \\
Rural Upper Egypt & $0.568(.311-1.035)$ & 0.065 \\
Rural Lower Egypt & $0.290(.162-.518)$ & 0.000 \\
Frontier Governorates & $0.259(.134-.499)$ & 0.000 \\
Urban Governorates & $0.181(.098-.334)$ & 0.000 \\
Urban Lower Egypt & $0.149(.080-.278)$ & 0.000 \\
Education of respondents: & & \\
$\quad$ Illiterate & $1($ baseline $)$ & 0.001 \\
Primary & $1.154(.766-1.738)$ & 0.495 \\
Preparatory & $0.843(.584-1.216)$ & 0.361 \\
Vocational secondary & $1.241(.685-2.248)$ & 0.476 \\
$\quad$ Secondary & $0.717(.546-.943)$ & 0.017 \\
Above secondary & $0.573(.413-.795)$ & 0.001 \\
Constant & 2.098 & 0.009 \\
\hline
\end{tabular}

\section{Discussion}

A total 3,226 of ever married females were included in this study. This study found that the majority ( $71 \%$ ) of studied women regardless age, or years of education, accepted violence against women and only $28.7 \%$ of respondents rejected gender based violence.

Kharboush et al., (2010) found that about $40 \%$ reported that the beating is justified if the wife goes out without telling her husband, neglects her children, argues with him, refuses to have sex with him, or burns the food [5].

This was in agreement with a study of Scott in South Sudan which found that $82 \%$ of women agreed with the statement 'a woman should tolerate violence in order to keep her family together'. The majority of respondents, $68 \%$ of women also agreed that 'there are times when a woman deserves to be beaten [6].

Another survey in South Africa found that the majority of women accept and agree that the husband has the right to beat his wife and moreover some of them enjoy punishment [7].

The results revealed that the respondents with older age at marriage (18 years or more) were more likely to reject (29.6\%) GBV than those with younger age at marriage (25.3\%). In a study in Zimbabwe found that Younger women are more likely to believe that wife beating is justified. than older women indicate that the next generation of women is just as likely to believe that wife beating is an acceptable behavior [8]
As regards the education level of respondents, our results revealed that there was more rejection of GBV with increasing the level of education. A survey in India found that women with higher levels of education are reducing their tolerance towards gender-based violence, meaning that individual-level improvements in education may only operate to reduce GBV at the community level [9] Another study carried out by Boyle et al., 2009 [10] shows that the influence of female education operates through changing community-andsocietylevel factors that reduce the acceptability of genderbased violence in general.

Similar to previous studies conducted in Egypt [11], this study found that women having fewer children had lower risk of beingexposed to GBV.

As regard wealth status, the results showed that the rejection of GBV attitude was increased with increasing the wealth quintile from the lowest level $(22.5 \%)$ to the highest level $(31.0 \%)$ with high significant difference.

Wealth status, education and urbanization had a greater negative impact on acceptance of GBV in this study. The limited effects seen in primary education alone compared to those with secondary or higher education is not surprising. Having few years of education usually at young age may not expose people to new non-traditional ideas [12].

There was no significant statistical difference between respondents who accepted the GBV and those who rejected it as regard the employment status. This was in accordance with the results of previous studies [13,14] whichfound that occupation status had minimal effect on acceptance of GBV. Most women in low-income countries work largely in informal sectors with low paid jobs.

A study in Australia [15] and the United States [16] found that attitudes toward violence against women vary with socioeconomic variables such as labor market participation and socioeconomic status. Both studies found an association between economic and social disadvantage and higher risks of violence and crime in general and intimate partner.

\section{Conclusion:}

- In general, only $28.7 \%$ of all ever married female youth rejected gender-based violence.

- Socio demographic characteristics play an important role on the attitude of ever married women towards violence. 
- Older ages at marriage (18 years and over) were more likely to reject GBV $(29.6 \%)$ than those with younger age at marriage $(25.3 \%)$.

- The urban residents rejected (35.6\%) GBV more than rural residents $(25.3 \%)$. This was demonstrated in urban Lower Egypt and urban governorates. In Upper Egypt whether rural or urban areas were the least likely to reject GBV.

- The rejection of GBV attitude was increased with increasing the wealth quintile from the lowest level $(22.5 \%)$ to the richest level (3 1.0\%).

- Education plays a key role in shaping the human development and opportunities of youth in Egypt. There were more rejections of GBV attitude with increasing the level of education of the respondents, fathers and mothers.

\section{Recommendations:}

- Parents, educational institutions, health care providers (eg. pre-marital counseling), civil society (mass media), community and religious leaders need to engage in more open dialog with young people to educate them about GBV, enforce positive attitude (multi-sectoralinterventions) and support economic and social development.

- In absence of credible sources of information, young people may turn to their peers, internet or mass media which may not necessarily provide accurate information.

\section{References}

1- United Nations Department of Economic and Social Affairs, Division for Sustainable Development, "Open Working Group Proposal for Sustainable Development Goals," accessed at http://sustainabledevelopment.un.org/ focussdgs.html, on Jan. 22, 2015.

2- European Commission. Domestic violence against women report. Brussels: DG Justice. Available at: http:// ec.europa.eu/public opinion/archives/ebs/ebs 344 en.pdf. 2010.

3- El-Zanaty and Associates Ministry of Health and Population, May 2015 Cairo, Egypt The DHS Program ICF International Rockville, Maryland, USA.

4- Alexandria Regional Centre for Women's Health and Development (ARC) and Ford Foundation, Violence Against Women in Alexandria: Quantitative Component (Alexandria, Egypt: ARC, 2010).

5- IBRAHIM F. KHARBOUSH, FARZANEH ROUDIFAHIMI, HANAA M. ISMAIL, HEBA M. MAMDOUH, YASMINE Y. MUHAMMAD, MAY M. TAWFIK, OM-
NIA G. EL SHARKAWY and HASSAN N. SALLAM: Spousal Violence In Egypt,2010 Policy Breif.

6- JENNIFER SCOTT, SARAH AVERBACH, ANNA MERPORT MODEST, MICHELE R. HACKER, SARAH CORNISH, DANIELLE SPENCER, MAUREEN MURPHY and PARVEEN PARMAR: An Assessment Of Gender Inequitable Norms and Gender-Based Violence in South Sudan: A Community-Based Participatory Research Approach. Confl. Health, 7: 4, 2013.

7- JULIA KIMA and MMATSHILO MOTSEI: "Women enjoy punishment": Attitudes and experiences of genderbased violence among PHC nurses in rural South Africa, Soc. Sci. Med., 54: 1243-54, 2002.

8- MICHELLE J.: Hindin 1 Understanding Women's Attitudes Towards Wife Beating In Zimbabwe Policy Brief, 2015.

9- ERNESTINA COAST, TIZIANA LEONE and ALANKARMALVIYA: Gender-Based Violence and Reproductive Health in Five Indian States, Gender-Based Violence and Public Health: International Perspectives on Budgets and Policies. New York, Routledge, 2012.

10- BOYLE M.H., GEORGIADES K. CULLEN J. and RACINE Y.: Community Influences on Intimate Partner Violence in India: Women's Education, Attitudes Toward Mistreatment and Standards of Living. Social Science \& Amp.; Medicine, 69 (5): P. 691-7, 2009.

11- MANAS K. AKMATOV, RAFAEL T. MIKOLAJCZYK, SHOKRIA LABEEB, ENAS DHAHER and MDMOBARAK KHAN: Factors associated with wife beating in Egypt: Analysis of two surveys (1995 and 2005), B.M.C. Womens Health, 8: 15, 2008.

12-OYEDIRAN K.A. and ISIUGO-ABANIHE U.: Perceptions Of Nigerian Women On Domestic Violence: Evidence From 2003 Nigeria DHS. African Journal of Reproductive Health, 9 (2): 38-53, 2005.

13- UTHMAN O.A., MORADI T. and LAWOKO S.: The Independent Contribution of Individual, Neighborhood, and Country-Level Socioeconomic Position on Attitudes Towards Intimate Partner Violence Against Women in Sub-Saharan Africa: A Multilevel Model of Direct and Moderating Effects. Soc. Sci. Med., 68 (10): 1801-9. Doi: 10.1016/J.Socscimed.2009.02.045, 2009.

14- RANI M., BONU S. and DIOP-SIDIBE N.: An Empirical Investigation of Attitudes Towards Wife-Beating Among Men and Women in Seven Sub-Saharan African Countries. African Journal of Reproductive Health, 8 (3): 116-36. Doi: 0.2307/3583398, 2004.

15- MARKOWITZ F.E.: Socioeconomic Disadvantage and Violence: Recent Research on Culture and Neighborhood Control as Explanatory Mechanisms. Aggression And Violent Behavior, 8: 145-54, 2003.

16- NAGEL B., MATSUO H., MCINTYRE K.P. and MORRISON N.: Attitudes Toward Victims of Rape: Effects of Gender, Race, Religion, And Social Class. Journal of Interpersonal Violence, 20: 725-37, 2005. 


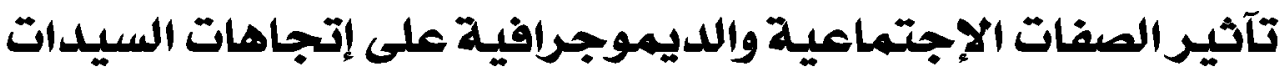

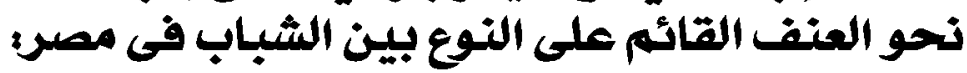

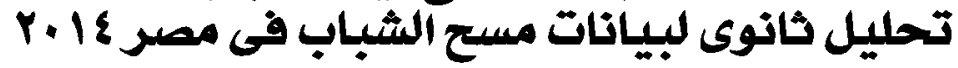

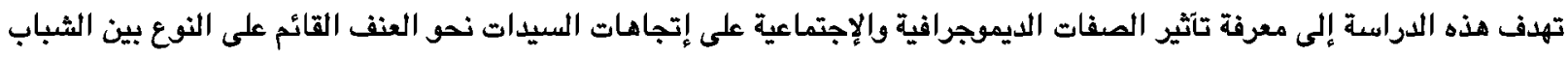

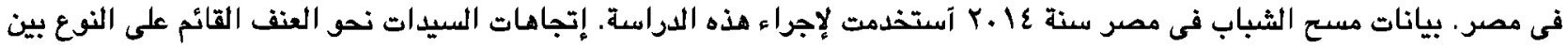

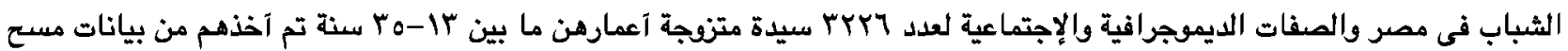

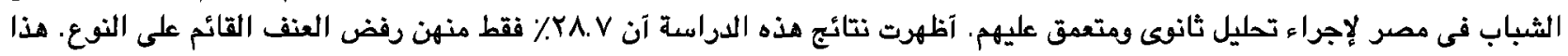

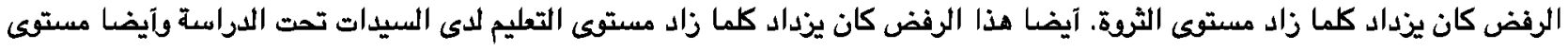

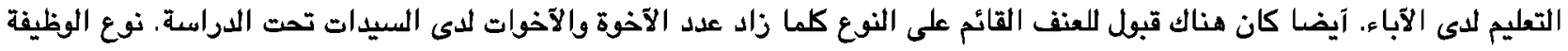

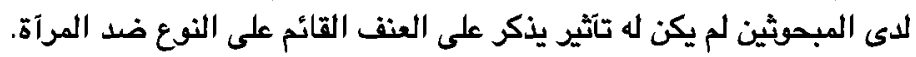

